\title{
Does Schistosoma Mansoni Facilitate Carcinogenesis?
}

\author{
Verena von Bülow ${ }^{1}$, Jakob Lichtenberger ${ }^{1}$, Christoph G. Grevelding ${ }^{2}{ }^{(D}$, Franco H. Falcone ${ }^{2}$, Elke Roeb ${ }^{1}(\mathbb{D}$ \\ and Martin Roderfeld ${ }^{1, *(1)}$ \\ 1 Department of Gastroenterology, Justus Liebig University, 35392 Giessen, Germany; \\ verena.von-buelow@innere.med.uni-giessen.de (V.v.B.); Jakob.J.Lichtenberger@med.uni-giessen.de (J.L.); \\ Elke.Roeb@innere.med.uni-giessen.de (E.R.) \\ 2 Institute of Parasitology, BFS, Justus Liebig University, 35392 Giessen, Germany; \\ Christoph.Grevelding@vetmed.uni-giessen.de (C.G.G.); Franco.Falcone@vetmed.uni-giessen.de (F.H.F.) \\ * Correspondence: martin.roderfeld@innere.med.uni-giessen.de; Tel.: +49-641-994-2527
}

Citation: von Bülow, V.;

Lichtenberger, J.; Grevelding, C.G.; Falcone, F.H.; Roeb, E.; Roderfeld, M. Does Schistosoma Mansoni Facilitate Carcinogenesis?. Cells 2021, 10, 1982. https://doi.org/10.3390/cells10081982

Academic Editor: Özlem Yilmaz

Received: 1 July 2021

Accepted: 1 August 2021

Published: 4 August 2021

Publisher's Note: MDPI stays neutral with regard to jurisdictional claims in published maps and institutional affiliations.

Copyright: (C) 2021 by the authors. Licensee MDPI, Basel, Switzerland. This article is an open access article distributed under the terms and conditions of the Creative Commons Attribution (CC BY) license (https:// creativecommons.org/licenses/by/ $4.0 /)$.

\begin{abstract}
Schistosomiasis is one of the most prominent parasite-induced infectious diseases, causing tremendous medical and socioeconomic problems. Current studies have reported on the spread of endemic regions and the fear of development of resistance against praziquantel, the only effective drug available. Among the Schistosoma species, only S. haematobium is classified as a Group 1 carcinogen (definitely cancerogenic to humans), causing squamous cell carcinoma of the bladder, whereas infection with S. mansoni is included in Group 3 of carcinogenic hazards to humans by the International Agency for Research on Cancer (IARC), indicating insufficient evidence to determine its carcinogenicity. Nevertheless, although S. mansoni has not been discussed as an organic carcinogen, the multiplicity of case reports, together with recent data from animal models and cell culture experiments, suggests that this parasite can predispose patients to or promote hepatic and colorectal cancer. In this review, we discuss the current data, with a focus on new developments regarding the association of $S$. mansoni infection with human cancer and the recently discovered biomolecular mechanisms by which $S$. mansoni may predispose patients to cancer development and carcinogenesis.
\end{abstract}

Keywords: S. mansoni; schistosomiasis; cancer; carcinoma; HCC

\section{Introduction}

Schistosomiasis is one of the most common parasitic infectious diseases worldwide, with at least 236 million people requiring preventive treatment in 2019 (WHO 2021) [1]. While the majority of people at risk live in the endemic regions of Africa, Schistosoma species are also prevalent in the Middle East, the Caribbean, South America, and Southeast Asia [2]. Schistosomiasis is increasingly being imported into regions with temperate climates by immigrants and travelers from endemic areas [3,4]. Epidemiological case studies of an outbreak of urogenital schistosomiasis in Corsica, France, and the transmission of African schistosomiasis in China underline the potential risk of schistosomiasis spreading into novel areas $[5,6]$. Two recently published studies analyzed the spread of the intermediate host, a freshwater snail, and zoonotic implications, which might be causative for the current expansion of schistosomiasis [7,8]. Moreover, the development of new hybrid species, which originated from humans via zoonotic spillover from livestock populations, has recently been described in areas where $S$. haematobium is co-endemic with $S$. bovis [9].

After contact with fresh water, these parasitic blood flukes infect their host by penetrating the skin as cercariae, the free-swimming infectious stage of schistosomes [10]. Adult male and female worms live within the venules of their human host, where they mate. Depending on the species, paired schistosomes can produce approximately 300-2000 eggs daily, which are deposited into the stool or urine to reach the environment for continuing their lifecycle [11].

There are three major species infecting humans: Schistosoma mansoni, Schistosoma haematobium, and Schistosoma japonicum [12]. Both S. mansoni and S. haematobium are present 
in Africa and the Middle East, while S. mansoni also occurs in South America. S. japonicum is confined to Asia, mainly China and the Philippines. Schistosomes live an average of 3-10 years but, in some cases, lifespans of nearly 40 years have been reported [13].

Following infection of the final host, schistosome cercariae develop to schistosomulae, the juvenile form of this blood fluke. Schistosomula migrate via the bloodstream to the liver, where they reach the adult stage. Male and female schistosomes pair, and, as couples, they migrate to the urogenital veins (S. haematobium) or mesenteric veins of the gut (S. mansoni). Following pairing, the male-dependent sexual maturation of the female is completed [14] and egg production starts. S. mansoni couples live within the mesenteric veins, where they produce eggs [2]. Chronification of schistosomiasis begins several weeks to months after the cercariae enter their definite host. The symptoms depend on the degree of worm infestation, the rate of oviposition, and the organ site of granulomatous entrapment of the eggs. During chronic stages of infection, half to two-thirds of the eggs are swept away in the circulation to multiple organs instead of being excreted via the stool [2]. The majority of those eggs end up in the liver, causing symptoms of hepatic schistosomiasis [2,11].

Simultaneously to the hepatic manifestation, intestinal schistosomiasis develops when eggs pass through or become trapped in the intestinal tissues [15]. Severe chronic infections with $S$. mansoni are mostly associated with hepatic and intestinal pathogenesis, while urogenital schistosomiasis is mainly caused by S. haematobium [10]. The eggs provoke a granulomatous host immune response, which induces chronic inflammation that leads to the pathologic manifestations of schistosomiasis, i.e., portal and pulmonary hypertension, bloody diarrhea, vaginal discomfort, hemospermia, nephropathy, and other organ-specific manifestations [15]. The granulomatous inflammation facilitates the translocation process of the eggs into the gastrointestinal lumen [15]. However, the egg granuloma also protects the host from an exaggerated immune response against the antigenic eggs [2].

In general, infections might initiate or promote carcinogenesis through chronic inflammation due to prolonged persistence of the inducing agent in the host [16]. Amongst other, infections can promote damage of the DNA, proteins, and cell membranes, as well as the modulation of enzyme activities and gene expression [17].

The global burden of cancer was estimated to be 19.2 million new cases and 10 million cancer-related deaths in 2020 [18]. Approximately 20\% of human cancers are caused by infectious diseases $[16,19]$. It was estimated that $0.4 \%$ of the new cancers attributable to infections were caused by the trematodes S. haematobium $(0.3 \%)$, Opisthorchis viverrini, and Clonorchis sinensis (both liver flukes together: $0.1 \%$ ), which are considered as Group 1 carcinogens by the International Agency for Research on Cancer (IARC) [18]. Infection with the liver flukes $O$. viverrini and $C$. sinensis increases the risk of developing cholangiocarcinoma, while in endemic areas, $46-75 \%$ of all bladder cancers can be attributed to S. haematobium [20]. Important references to schistosomiasis and cancer date back to the 1940s [21-23]. Among the Schistosoma species, only S. haematobium is classified as a Group 1 carcinogen (definitely cancerogenic to humans), causing squamous cell carcinoma of the bladder, whereas infection with S. mansoni is included in Group 3, indicating insufficient evidence to determine its carcinogenicity [24]. In addition, a related liver fluke, Opisthorchis felineus, is also classified as a Group 3 agent in a similar manner to S. mansoni. Several reports have linked infection with Opisthorchis felineus to cancer $[25,26]$. Interestingly, vaccination against $S$. haematobium has been discussed as an important major public health achievement in preventing cancer, similar to hepatitis B vaccines and HPV vaccines [27]. The question 'Why does infection with some helminths cause cancer?' has been intensively discussed and reviewed in the context of S. haematobium, O. viverrini, and C. sinensis [28]. For these three species, even concrete concepts of chemical carcinogenesis, including malignant molecular mediators as well as mechanisms such as the formation of DNA adducts of parasite-released oxysterols and estrogen-like metabolites, have been suggested [29-31]. A future-oriented concept might be to study the known carcinogenic mechanisms induced by S. haematobium, O. viverrini, and C. sinensis in models of $S$. mansoni infection. 
The data linking S. mansoni to cancer are insufficient and, in part, conflicting [32,33]. Nonetheless, case reports and descriptive studies from endemic regions have discussed the possibility of an association between S. mansoni infestation and cancer, including hepatocellular carcinoma (HCC) [33-42], colorectal cancer (CRC) [43-48], bladder carcinoma [49], prostate cancer [50], and follicular lymphomas [51,52]. Although S. mansoni is classified as a Group 3 carcinogen, the multiplicity of case reports, together with data from animal models and cell cultures, suggests that $S$. mansoni can at least predispose a patient to- or promote cancer. Overall, the epidemiological evidence associating $S$. mansoni infection with cancer is lacking, and studies are often of poor quality or conflicting. Therefore, wellplanned, rigorous epidemiological, experimental, and clinical studies are urgently needed to determine the cause-effect relationship between $S$. mansoni and malignancy, and to define the molecular mechanisms involved. In this review, we summarized current data on the association of $S$. mansoni infection with human cancer and reviewed the biomolecular mechanisms by which $S$. mansoni may predispose a patient to cancer development and promote carcinogenesis, as schematically merged in Figure 1.
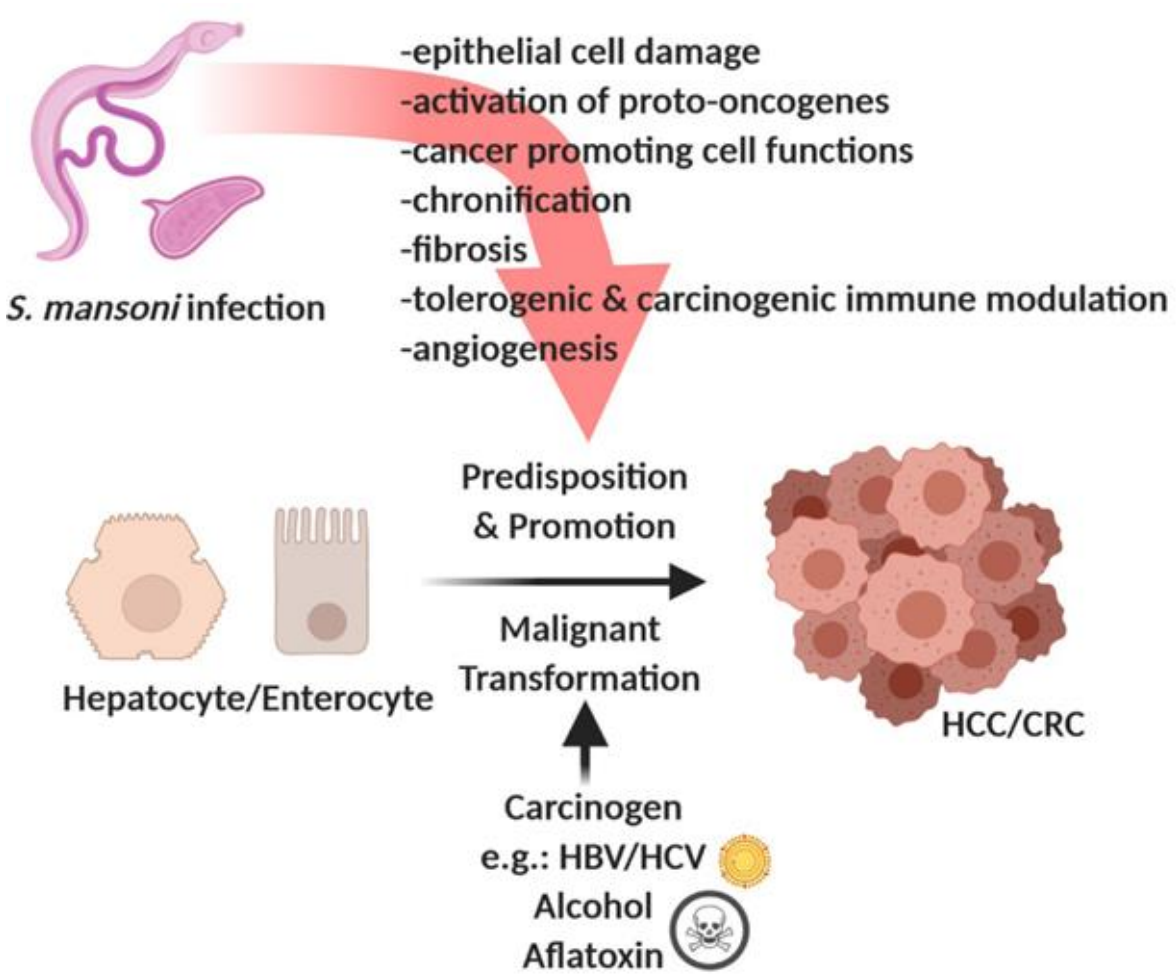

Figure 1. Infection with $S$. mansoni induces processes predisposing a patient to malignant transformation and/or promoting hepatocellular carcinogenesis (HCC) and/or colorectal carcinogenesis (CRC). Created with BioRender.com, online link: https:/ / biorender.com/, (accessed on 25 March 2021).

\section{Search Strategy and Selection Criteria}

For the literature retrieval and study selection process, Medline was searched via the internet using the search engine PubMed (http: / / www.ncbi.nih.gov / entrez/query.fcgi, accessed on 23 March 2021). The aim of the literature search strategy was to identify case reports and scientific studies of $S$. mansoni infection associated with cancer. The primary search retrieved all studies published between 1980 and 2020 using the following search terms: "Schistosoma" OR "Schistosoma mansoni" OR "Schistosomiasis" (title and abstract) AND/OR "HCC OR hepatocellular cancer" OR "CRC OR colorectal cancer" (title and abstract) AND "HBV" OR "HCV" OR "IPSE" (title and abstract) AND "1980-2021" (publication date) AND “journal article" (publication type) AND "English OR German" (language). A secondary search was conducted to locate reviews and editorials. The reference lists of all retrieved papers were searched manually to detect additional hits 
not found by the primary Medline search. All the selected studies had been published as full papers. For the current review, the choice of studies was focused on papers targeting malignancy in the context of S. mansoni infection.

\section{Hepatic Schistosomiasis}

Hepatic schistosomiasis results from the host's granulomatous cell-mediated immune response and the metabolically active and highly antigenic ova of S. mansoni. The eggs are swept from the mesenteric veins into the small portal branches of the liver via the portal vein, where they are trapped in the pre-sinusoidal periportal tissues. At the site of egg deposition, an excessive granulomatous response develops, which is harmful to the liver by provoking progressive fibrosis. This can impair the blood flow and thereby induce portal hypertension [12,53]. Progressive fibrosis in the portal tract often leads to obstructive portal lesions and portal hypertension, and might result in hepatomegaly, often in combination with splenomegaly, gastrointestinal bleeding, ascites, hepatic encephalopathy, and liver failure [2]. This severe form of schistosomiasis might be fatal. Hepatic fibrosis displays a wound-healing process, with progressive replacement of functional parenchyma by the extracellular matrix $[54,55]$. Hepatic stellate cell (HSC) activation and their trans-differentiation into myofibroblasts causes an overproduction of the extracellular matrix (ECM), thus leading to increased vascular resistance, dysregulation of inflammatory responses, and cirrhosis [56,57]. Regarding S. mansoni infection, the time from initial infection to advanced fibrosis is usually $5-15$ years [12].

HCC represents a fatal outcome of chronic liver disease of different etiologies, which is the fourth-leading cause of cancer-related deaths globally [58]. The risk of HCC depends on hepatic background factors, of which chronic inflammation and fibrosis are major determinants [59]. Patients with liver fibrosis of any etiology belong to the high-risk group for the development of HCC $[60,61]$. The increase in the incidence of HCC in recent years is partly attributable to the increase in Type 2 diabetes and metabolic syndrome, which can result in non-alcoholic fatty liver disease (NAFLD) and especially in non-alcoholic steatohepatitis (NASH), with or without fibrosis [62-64].

The mechanisms involved in oncogene activation, tumor suppressor gene inactivation, chromosomal rearrangement in combination with immune- and inflammatory responses such as the induction of auto-aggressive $\mathrm{CXCR}^{+} \mathrm{CD}^{+} \mathrm{T}$-cells and $\mathrm{PD} 1^{+} \mathrm{CD} 8^{+} \mathrm{T}$-cells, telomere shortening, DNA damage, oxidative stress, and autophagy are crucial for HCC development [65-69]. The relationship between HCC and S. mansoni has been debated in human cases [32,33]. Most Schistosoma-associated HCC cases develop in the presence of advanced chronic liver disease related to chronic hepatitis $\mathrm{C}$ virus (HCV) infection, chronic HBV infection, and alcohol abuse [34]. Both HBV and HCV are considered to be major causes of the progression to liver cirrhosis and HCC [70]. Co-infection with S. mansoni and HCV or HBV is common in regions where schistosomiasis occurs endemically [71]. The available literature indicates that the co-infection with Schistosoma and HBV or HCV likely acts as a cofactor by prolonging the carriage state and resulting more often in chronic hepatitis with fibrosis, as well as higher mortality [34]. A study from Egypt reported on a higher HCC occurrence in patients with co-infection with HCV and S. mansoni, suggesting an increased incidence with co-infection [32]. In patients with concomitant $\mathrm{HCV}$ and schistosomiasis, HCC was more commonly multifocal and advanced.

Several studies have shown that distinct $\mathrm{T}$ cell subpopulations have specific roles not only in immune defense but also in maintaining immune homeostasis. Disturbance of this balance can lead to undesirable side effects such as inflammation, susceptibility to infection, or even autoimmune phenomena, such as the induction of auto-aggressive $\mathrm{CXCR6}^{+} \mathrm{CD}^{+} \mathrm{T}$ cells and PD1 ${ }^{+} \mathrm{CD} 8^{+} \mathrm{T}$ cells in the context of NASH $[66,69]$. Patients co-infected with S. mansoni and HCV exhibited a dominant Th2 response, while the HCVinduced Th1 response was downregulated [72]. Programmed Cell Death Protein 1 (PD-1) plays a vital role in inhibiting immune responses and promoting self-tolerance [73]. As PDL1 plays an important role in various malignancies, therapeutic modulation of PD-1/PD-L1 
signaling is currently being investigated in order to generate novel therapeutic anticancer strategies [73]. Most intriguing, PD-1 signaling is disturbed by S. mansoni [74], which may indicate a possible link between S. mansoni-promoted carcinogenesis and PD-L1. Moreover, it has been shown that the blockade of PD-1 signaling enhanced the Th2 cell responses and aggravated liver immunopathology in mice infected with S. japonicum [75].

There is evidence that the cancer environment generated by the host's inflammatory cells is a crucial element in the neoplastic process [76]. Infection with S. mansoni induces a predictable immunological reaction in the host, a Type 1 immune-dominated response in the acute phase reaction, mainly targeted at worm antigens and characterized by interleukin (IL)-12 and interferon (IFN)- $\gamma$ [2]. The early Th1 response switches to a Th2-dominated response after the onset of parasite egg production. The release of cytokines such as IL-4, IL-5, IL-10, and IL-13 is a hallmark of the egg-induced granulomatous host immune response driven by Type 2 lymphocytes [77]. S. mansoni antigen-induced cytokine production [78], T-cell proliferation, and in vitro granuloma formation involve the activation of protein tyrosine kinases (PTKs) and protein kinase C (PKC) [79]. It has been speculated that immunomodulation might either influence PTKs activity or be the result of altered PTK regulation [80]. Interestingly, SEA-stimulated $\mathrm{CD} 4^{+} \mathrm{T}$ cells from S. mansoni-infected patients had a lower proliferation rate than the same cells from the non-infected group [81]. Most importantly, S. mansoni treatment reduces HIV entry into cervical CD4 ${ }^{+} \mathrm{T}$ cells and induces IFN-I pathways [82]. This observation may open a new venue for HIV therapy, as S. mansoni infection has been linked with an increased risk of HIV acquisition in women [82]. The authors concluded that the identification of the signaling pathways and mechanisms by which treatment of $S$. mansoni infection could reduce female HIV acquisition is an important step toward designing effective HIV prevention programs [82]. Nevertheless, it is still rather uncertain whether these signal transduction pathways may be involved in S. mansoni-associated carcinogenesis. Moreover, recent studies have shown that Th9, Th17, and T follicular helper cells (Tfh) cells might also promote hepatic granulomas and fibrogenesis in schistosomiasis [77]. Additionally, hepatic stellate cells, alternatively activated macrophages, eosinophils, and regulatory $\mathrm{T}$ cells have been implicated in the fibrogranulomatous reaction [12]. Regulatory T cells and alternatively activated macrophages in carcinogenesis suppress anti-tumor immune responses and contribute to the development of an immunosuppressive tumor microenvironment, thus promoting immune evasion and cancer progression $[83,84]$.

It is important to emphasize that the schistosome eggs are bioactive entities that proactively interact with the host to achieve their excretion. To this end, the eggs actively manipulate the host's immune system [2]. The effect of schistosome eggs on host cells can be studied by co-culturing but also by stimulating host cells with egg-conditioned media, soluble egg antigens (SEA), purified biomolecules from the eggs, and recombinantly produced egg proteins. SEA of $S$. mansoni bear hundreds of glycosylated proteins with immunomodulatory potential [85]. Among these, the glycoproteins alpha-1/IL4-inducing principle from S. mansoni eggs (IPSE/ $\alpha 1$ ) and omega-1 $(\omega-1)$ are the most abundant and require interactions with selective C-type lectins on immune cells [86-88]. IPSE/ $\alpha 1$ has a C-terminal nuclear localization signal (NLS) that conveys "infiltrin" activity, the ability to infiltrate the nucleus by crossing the cell and nuclear membranes [89,90]. Importantly, IPSE / $\alpha 1$ further contributes to enlargement of hepatic granulomas [91]. IPSE [92] binds to immunoglobulins, with a high affinity for IgE [88]. Once IPSE binds to IgE-bound FceRI receptors on the surface of basophils, it triggers the release of IL-4 and IL-13 [89,93], which directly induces the differentiation of monocytes into the alternatively activated macrophage-like M2 phenotype.

$\omega-1$ is a member of the T2 RNase family, which enters the cell by binding to the mannose receptor on dendritic cells [2], subsequently being internalized into the cell and degrading cellular mRNA and rRNA products. $\omega-1$ has been identified as a powerful Th2-inducing factor. Both the RNase activity and the glycan group are essential for Th2 skewing $[87,94]$. 
The identification and characterization of trematode antigens is a relatively young discipline and few data about carcinogenic effects of these antigens have been published yet. Table 1 summarizes the carcinogenesis-associated mechanisms that can be induced by IPSE, a major component secreted from schistosomal eggs, along with a list of the analogous antigens of known Group I carcinogens:

Table 1. Table summarizing the identified parasite-derived proteins with suspected pro-carcinogenic activity. BLCA, bladder cancer; CC, cholangiocarcinoma; CRC, colorectal carcinoma; HCC, hepatocellular carcinoma; SCC, squamous cell carcinoma.

\begin{tabular}{|c|c|c|c|c|}
\hline Molecule & Effect & $\begin{array}{c}\text { Type of Cancer Associated } \\
\text { with Infection }\end{array}$ & $\begin{array}{c}\text { Expressing } \\
\text { Lifecycle Stage }\end{array}$ & Reference (PMID) \\
\hline \multicolumn{5}{|c|}{ Opisthorchis viverrini } \\
\hline $\begin{array}{l}\text { Granulin } \\
(\text { Ov-GRN-1) }\end{array}$ & $\begin{array}{l}\text { angiogenesis } \\
\text { wound healing } \\
\text { proliferation }\end{array}$ & CC & $\begin{array}{l}\text { eggs, metacercariae, } \\
\text { juveniles, adults }\end{array}$ & $\begin{array}{l}25450776 \\
26485648 \\
19816559\end{array}$ \\
\hline & & Clonorchis sinensis & & \\
\hline CsGRN & $\begin{array}{l}\text { cell migration } \\
\text { and invasion }\end{array}$ & $\mathrm{CC}, \mathrm{HCC}$ & adults & 28545547 \\
\hline Csseverin & anti-apoptotic & Schistosoma haematobium & metacercariae and adults & 24367717 \\
\hline IPSE $/ \alpha 1$ & $\begin{array}{c}\text { proliferation } \\
\text { and angiogenesis }\end{array}$ & BLCA, SCC & eggs only & 33101456 \\
\hline IPSE $/ \alpha 1$ & $\begin{array}{c}\text { proliferation, } \\
\text { c-Jun and STAT3 } \\
\text { activation }\end{array}$ & $\begin{array}{l}\text { Schistosoma mansoni } \\
\text { HCC } \\
\text { CRC }\end{array}$ & eggs only & $\begin{array}{l}30053321 \\
33361772\end{array}$ \\
\hline
\end{tabular}

Nevertheless, also other biologically active substances released by S. mansoni eggs might influence their carcinogenic potential. It has been shown that $S$. mansoni alters the levels of steroid hormones, which may change the status of the cancer environment by affecting the endocrine system [95].

The firmly established Th2 milieu in chronic schistosomiasis is critical for the subsequent reduction of the T-cell response and immunopathology, and also for the development of fibrosis [96]. Thus, this Th2 milieu might be involved in the progression of malignancy, as Th2 cytokines are related to cancer growth or metastasis [97,98]. Regulatory B-cells (Bregs) accelerate HCC formation by induction of the growth and migratory potential of cancer cells [99]. Schistosome egg antigens, including the glycoprotein IPSE/ $\alpha 1$, trigger the development of Bregs [100]. Additionally, Bregs are capable of producing IL-10, which induces Treg differentiation, thereby supporting a tolerogenic microenvironment [100]. While inflammatory injury drives both fibrogenesis and carcinogenesis, the tolerogenic microenvironment of the liver conveys immunosuppressive effects that encourage cancer growth [101]. In particular, the prevalence of Tregs is strongly correlated with HCC progression [102]. In schistosomiasis, regulatory T-cells (Tregs) exert an immunosuppressive role to limit the granulomatous inflammation and fibrosis [77].

The dominant Th2 response of S. mansoni infection might have therapeutic activity, e.g., reducing the incidence and development of diabetes in NOD mice [103]. Metabolic changes correlated with the eggs deposited in the liver have been shown in S. japonicuminfected mice, indicating the promotion of glycolysis-related genes on the one hand and downregulation of gluconeogenesis-related genes on the other hand [104]. In addition to the metabolic changes induced by the schistosome ova, SEA have the potential to alter cancerogenic signaling at the molecular level in vitro and in vivo $[105,106]$. In cancer progression, metabolic reprogramming, oxidative stress, and DNA damage display crucial events. Whether $S$. mansoni SEA induce metabolic changes in the liver or even a reprogramming of the hepatic glucose metabolism remains ambiguous. However, it is tempting to speculate that the eggs benefit from the host's metabolic environment to ensure their own survival, thereby disturbing the host';s metabolic balance. 
Studies on animal models have demonstrated amelioration of arthritis [107,108], colitis [109-111], Type 1 diabetes [112], and sepsis [113] with concomitant schistosome infection through induction of Th2-specific and immune modulatory cytokines IL-4, IL-5, IL-13, and IL-10 and suppression of Th1-specific cytokines IL-1 $\beta$, IL-6, IL12, TNF $\alpha$, and IFN $\gamma$. In this context, it is interesting to note that the protective effect of S. japonicum infection in an arthritis model is infection stage-dependent and was attributed to the Th2dominated response after the onset of parasite egg production, while the early Th1 response in schistosomiasis exacerbated arthritis $[108,114]$. In addition, S. mansoni can induce Foxp $3^{+}$ Tregs, tolerogenic dendritic cells (DCs), and alternatively activated macrophages, which provide protective effects in arthritis [115], colitis [111,116], autoimmune diseases [117], Type $1[112,118]$ and Type 2 diabetes [119,120], and sepsis [121].

Although the above mentioned positive immune modulatory effects of schistosomiasis and schistosomal products have been shown for different diseases, the Th2 milieu, Tregs, and tolerogenic DCs are known to suppress tumor-specific immune responses, thus establishing an immunosuppressive tumor microenvironment [83], which may account for the procarcinogenic properties of S. mansoni infections.

The role of $S$. mansoni as a risk factor for developing HCC was studied in a mouse model by inducing HCC with diethylnitrosamine (DEN) and concomitant schistosomiasis [122]. The cancerogenic effect of DEN was enhanced by S. mansoni. This led to the conclusion that $S$. mansoni is able to accelerate dysplastic changes in the presence of another risk factor, thus promoting cancer development, which appeared to be more aggressive in the presence of $S$. mansoni [122]. However, in this early study, it became clear that data are missing to explain how infection with $S$. mansoni may predispose patients to HCC development and how S. mansoni alters cancer growth, angiogenesis, and metastasis. In the liver of DEN-treated mice, infiltrating macrophages may facilitate the initiation of cancer development by the release of TNF- $\alpha$ and IL-6, which are able to activate essential morbidity-associated nuclear factors and signaling pathways such as NF- $\mathrm{KB}$ and STAT3 in HCC progenitor cells $[114,123]$. Aberrant NF- $\mathrm{kB}$ and STAT3 signaling is important for cell survival, and it has been involved in the pathogenesis of most human malignancies $[124,125]$. In this context, it has been demonstrated that $S$. mansoni infection caused mitochondrial damage, resulted in the release of ROS and superoxide, and upregulated NF- $\mathrm{KB}$ (p65) expression [126]. Thus, it appears likely that $S$. mansoni-dependent activation of NF- $\mathrm{KB}$ signaling in DEN-treated mouse livers may provide cancer cells with a survival advantage by the forced induction of anti-apoptotic genes.

Macrophages and eosinophils generate free radicals and nitrogen species in response to parasites [127]. These products can oxidize and damage DNA, induce DNA mutations, and may lead to genetic instabilities and malignant transformation [116]. Dysregulation of the enzymatic antioxidant system has been observed in a S. mansoni-infected mouse model. This was accompanied by the significantly lower activity of superoxide dismutase but increased catalase activity in the liver [128].

An Egyptian study with subjects infected with S. mansoni, S. haematobium, or both in parallel analyzed the most frequent mutations in human HCC [129]. A mutation in codon 249 of the p53 gene was identified in populations exposed to a high dietary intake of aflatoxin B1(AFB1) [129]. S. haematobium is known to cause mutations in the p53 gene. The combination of schistosomiasis and aflatoxin B1 increased the incidence of p53 gene mutations [129]. The mutations in codon 249 of the p53 gene were increased in patients infected with $S$. haematobium compared with those infected with S. mansoni or a combination of both species and compared with control subjects [129]. No p53 gene mutation was detected in hepatic DNA from schistosomiasis-free patients [129]. Significant amounts of N7-guanine-AFB1 adducts and novel adenine adducts $(p<0.01)$ were detected in patients with schistosomiasis, mostly in patients infected with S. haematobium or a combination of both species, suggesting that schistosomiasis and exposure to aflatoxin B1 act synergistically to increase the incidence of p53 gene mutations [129]. The authors concluded that the increase in p53 mutations might enhance the progression of HCC at an early age in patients 
with schistosomiasis [129]. Discrete mutation profiles that differ between liver flukeassociated cholangiocarcinoma and non-liver fluke-associated cholangiocarcinoma have been described [130]. In this regard, the identification of mutational signatures for HCC with concurrent infection with $S$. mansoni might be a promising approach to gain further insights into the mechanisms that might link S. mansoni to HCC.

Data from a hamster model, cell culture studies, and human biopsies provided evidence that antigens released from the $S$. mansoni ova are able to modulate host-specific cancerogenic pathways by activation of c-Jun and STAT3, correlating with cell-cycle activation and DNA double-strand breaks [106]. In vitro experiments with primary hepatocytes and Huh7 revealed that the activation of c-Jun and STAT3 as well as DNA repair were induced by soluble egg antigens (SEA) and egg-conditioned medium, and, in particular, by IPSE/ $\alpha 1$. STAT is constitutively expressed in cancer cells and is involved in cancerogenesis and survival [131]. Furthermore, the constitutive activation of STAT3 inhibited the maturation of dendritic cells through enhanced expression of IL-10 and VEGF. Blocking STAT3 resulted in the activation of both the innate and adaptive anti-tumor immune responses [132]. c-Jun is a major regulator of survival and proliferation during hepatic regeneration $[133,134]$. In vivo studies have underlined the importance of c-Jun for the induction and survival of liver cancer $[135,136]$. The HCV core protein potentiated chemically induced HCC through c-Jun and Stat3 activation in transgenic mice, which, in turn, enhanced cell proliferation, suppressed apoptosis, and impaired oxidative DNA damage repair, finally leading to hepatocellular transformation [137]. The permanent activation of hepatocellular carcinoma-associated proto-oncogenes such as c-Jun and the associated transcription factors, including Stat3, by substances released from tissue-trapped schistosome eggs may represent important factors contributing to the development of liver cancer, e.g., in HBV or HCV patients with concomitant S. mansoni infection [106].

Schistosome-induced angiogenesis has been described in human studies and experimental models. During murine infection, vascularization was found to be significantly enhanced in regions with a high egg concentration. In addition, the protein level of the pro-angiogenic factor VEGF was significantly higher in human subjects. Inhibition of angiogenesis by endostatin in infected mice reduced hepatic egg deposition, worm load, and mRNA expression of hepatic VEGF $[138,139]$. Studies identified living eggs and SEA as the inducers of endothelial proliferation [140], which may promote angiogenesis within hepatic granulomas by upregulating endothelial cell VEGF. The conditions created by vessel occlusion, such as hypoxia, acidic aid $\mathrm{pH}$, and low glucose concentrations, may also contribute to the observed neovascularization [141]. Similar to what has been observed in cancer, the growth of new vessels would maintain blood flow in scenarios of vessel occlusion, which would enable the recruitment of leucocytes to developing granulomas and ensure an adequate supply of oxygen and nutrients at these sites [15].

Figure 2 summarizes the known biomolecular factors and pathways induced by S. mansoni that alter cellular processes such as proliferation, apoptosis, or DNA damage that are linked to malignant hallmarks such as immune escape, survival, or tumor growth. 


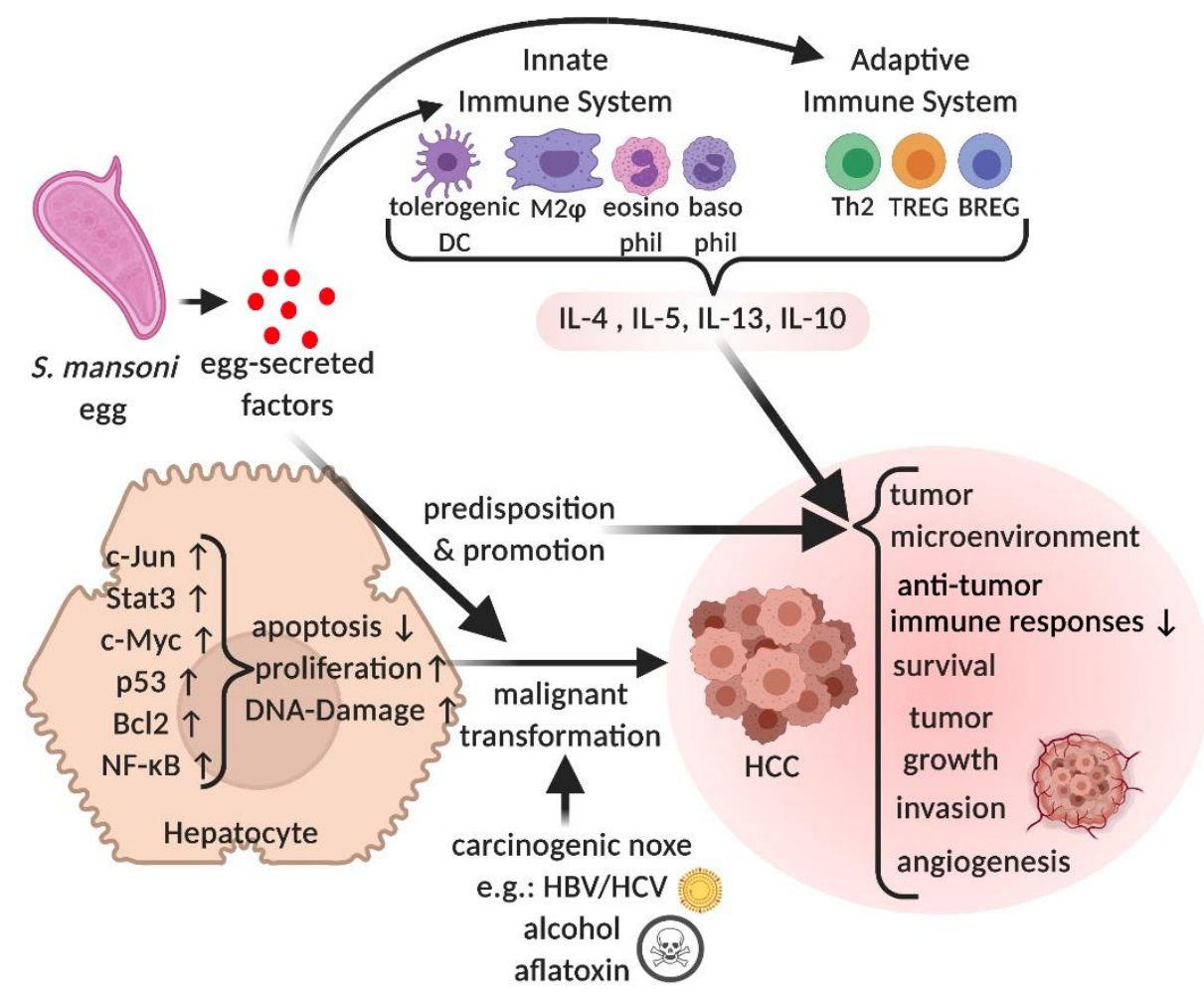

Figure 2. Egg-secreted factors induce tolerogenic and cancer-promoting immune modulations, i.e., the suppression of anti-tumor immune responses, and contribution to the development of an immunosuppressive tumor microenvironment. Egg-secreted factors trigger cellular processes that may predispose hepatocytes to neoplastic transformation or promote malignancy. Created with BioRender.com, online link: https: / / biorender.com/ (accessed on 25 March 2021).

\section{Intestinal Schistosomiasis}

Globally, colorectal cancer (CRC) is the third most commonly diagnosed malignancy and the second leading cause of cancer death [142]. Advanced colon polyps are strong risk factors for colorectal cancer [143]. The primary presenting symptoms of intestinal schistosomiasis are usually tenesmus and the rectal passage of blood and mucous and bloody diarrhea [144]. Egg deposition and granuloma formation eventually lead to acute then chronic schistosomal colitis and are commonly associated with polyp formation [145-148]. The preferential site of schistosomal polyps is the rectum, followed by the sigmoid colon [149]. Histopathological evaluation of the polyps revealed granulomatous inflammation with multiple, mostly calcified S. mansoni eggs in the center [145-147,150]. Several case reports have described the associations of $S$. mansoni with prostate adenocarcinoma and colorectal cancer $[43,45,46,50]$. It has been shown that $S$. mansoni-associated colorectal cancer is characterized by a high percentage of synchronous tumors and mucinous adenocarcinomas, and a higher frequency of advanced Stage III and IV tumors [46]. Schistosomal CRC (SCRC) shares unique characteristics independently of the Schistosoma species:

a. SCRC occurs at a younger age - 6-16 years earlier than ordinary CRC [21,46,151-153]which could be due to early environmental exposure to schistosomal infections in childhood. Preschool-aged children may already have been exposed to this disease [154].

b. SCRC incidence is consistently higher in males $[46,151,153]$. This male predominance was related to greater employment in agricultural work, and higher rates of contact with water, such as in workers busy with car washing [155].

c. SCRC appears preferentially in the rectum, with a mucinous histology $[46,156,157]$.

Contrarily, one study demonstrated that treatment with $S$. mansoni antigens reduced the number of tumors and the diameter of 1,2-dimethylhydrazine-induced CRC in mice [158]. 
The authors hypothesized that the protective effects resulted from a S. mansoni antigeninduced non-specific immune response or a cross-reactive adaptive immune response induced by S. mansoni glycosylated antigens [158].

There are only a few data available about the molecular mechanisms of intestinal schistosomiasis from S. mansoni infection analyzing the dysregulation of the malignant colon. A recent study described a DNA repair defect and a RAS mutation in two patients with S. mansoni-associated CRC [159]. The authors discussed whether these mutations might have been crucial for carcinogenesis or mere coincidence [159]. Several studies indicated the involvement of p53 [46,48,160]. Madbouly et al. found a significantly higher expression of p53 in SCRC compared with non-S. mansoni-infected CRC patients [46]. In contrast, in another study with 75 Egyptian CRC specimens, Zalata et al. found similar expression patterns of p53 and c-Myc in both groups, but significantly more SCRC patients were Bcl-2 positive compared with CRC patients without $S$. mansoni infection [48]. Bcl-2 was positivity correlated with greater apoptotic activity in cancers of the non-infected group. Zalata et al. concluded that the genotoxic agents produced endogenously during S. mansoni infection might be involved in the pathogenesis of CRC, with the overexpression of Bcl-2 leading to a reduction in programmed cell death in potential latent cancer foci [48]. In the study of Nacif-Pimenta et al., the regulatory effects of eggs from S. mansoni and S. haematobium on epithelial cell lines from the urinary and biliary tract were investigated in vitro [160]. It was demonstrated that $S$. haematobium eggs had a higher potential to induce proliferation in epithelial cells [160]. Nevertheless, gene expression analysis of oncogenes in human urothelial cells confronted with both schistosome species revealed that only S. mansoni eggs induced a significant dysregulation of the CRC signaling pathways, including the upregulation of TNF, RUNX1, the proto-oncogenes c-Myc and c-Jun, NF- $\mathrm{kB1}$, Scr, and Bcl-2 [160]. In contrast, p53-associated pathways were downregulated by both S. mansoni and S. haematobium eggs [160]. Previously, we reported the upregulation of the $\mathrm{JNK} / \mathrm{c}$-Jun signaling pathway in the liver of $S$. mansoni-infected hamsters, human liver samples, and primary liver cells exposed to S. mansoni SEA [106]. Interestingly, a similar activation pattern of the proto-oncogene c-Jun was discovered in epithelial colon cells and colon specimens exposed to S. mansoni SEA [105]. Urothelial cells co-cultured with either S. mansoni eggs or S. haematobium eggs resulted in the upregulation of WNT5a and WNT5b, which have been implicated in CRC via the non-canonical WNT signaling pathway [161]. Activation of the non-canonical WNT signaling pathway was also found in epithelial colon cells exposed to SEA [105]. Hence, it can be speculated that the carcinogenicity of chronic infection with schistosomes may not only depend on the schistosome species but also on the host tissue exposed to SEA.

\section{Conclusions}

Egg-triggered processes such as the activation of protooncogenes, Th2-immune modulation, and the tolerogenic reprogramming of DC and Tregs may be molecular triggers for S. mansoni-promoted carcinogenesis. Clinical data including more extensive cohort studies about affected patients may allow better insights into the association of S. mansoni with HCC and CRC. Globalization, the expansion of endemic areas, the justified fear of developing resistance to praziquantel, and the association with malignancy may underline the urgency to find new ways to control schistosomiasis.

Author Contributions: Conceptualization, V.v.B. and M.R.; investigation, V.v.B. and M.R.; methodology, V.v.B. and M.R.; project administration, M.R.; resources, C.G.G., F.H.F., E.R. and M.R.; supervision, M.R. and E.R.; validation, J.L., C.G.G., F.H.F. and E.R.; visualization, M.R.; writing-original draft, V.v.B. and M.R.; writing-review and editing, V.v.B., J.L., C.G.G., F.H.F., E.R. and M.R. All authors have read and agreed to the published version of the manuscript.

Funding: This work was supported by grants from the German Research Foundation (RO3714/4-1, RO957/10-1), GILEAD (support for the program Infectiology 2017), and the University Hospital of Giessen and Marburg (UKGM). The work was funded by the excellence initiative of the Hessian 
Ministry of Science, Higher Education and Art (HMWK) supporting the LOEWE Centre DRUID, awarded to C.G.G. and F.H.F., and additionally with flexible funds to E.R. and M.R.

Conflicts of Interest: The authors declare no conflict of interest. The funders had no role in the writing of the manuscript or in the decision to publish the review.

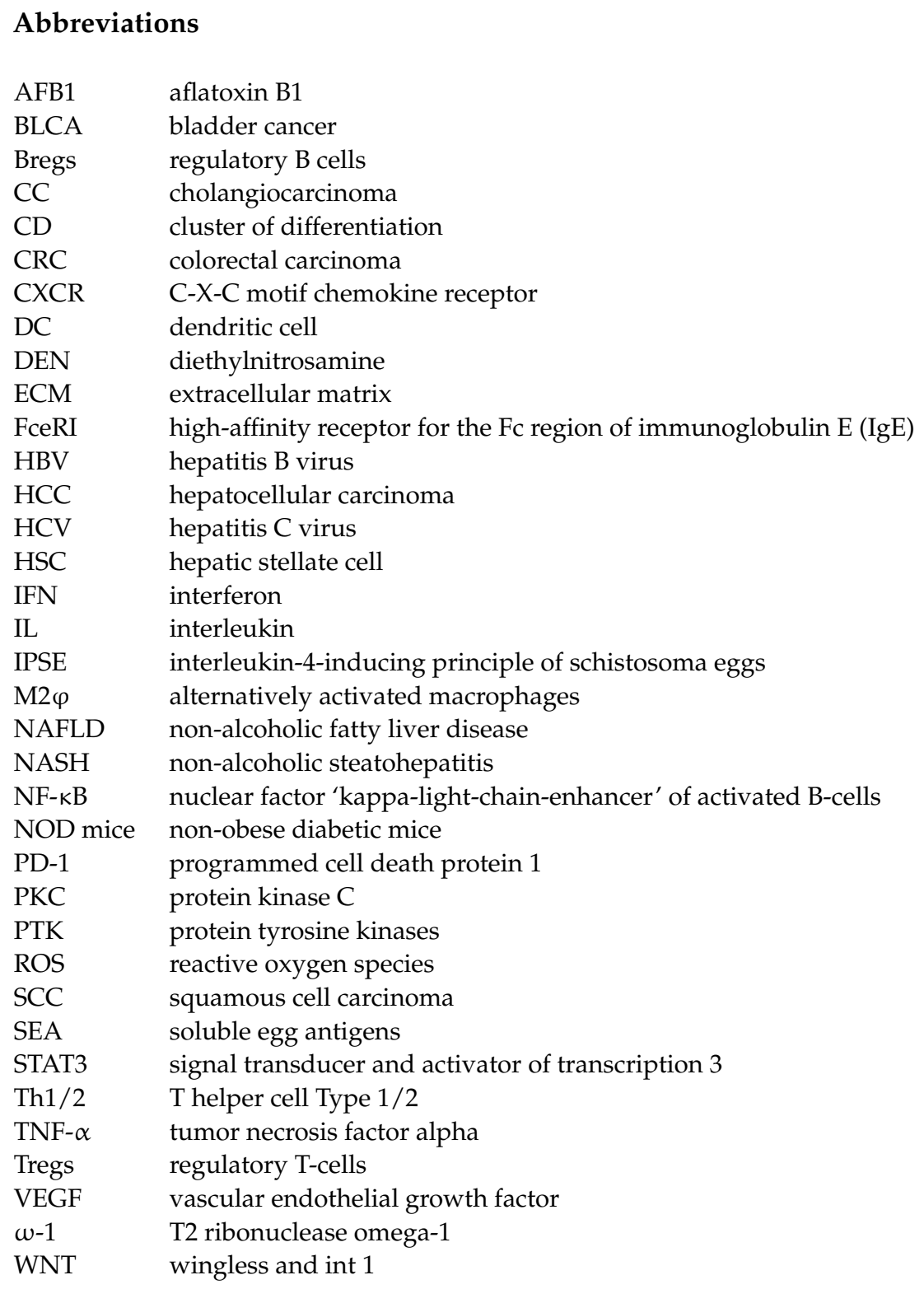

\section{References}

1. WHO Fact-Sheets Schistosomiasis. Available online: https://www.who.int/news-room/fact-sheets/detail/schistosomiasis (accessed on 20 May 2021).

2. Schwartz, C.; Fallon, P.G. Schistosoma "eggs-iting" the host: Granuloma formation and egg excretion. Front. Immunol. 2018, 9, 2492. [CrossRef]

3. Lingscheid, T.; Kurth, F.; Clerinx, J.; Marocco, S.; Trevino, B.; Schunk, M.; Muñoz, J.; Gjørup, I.E.; Jelinek, T.; Develoux, M.; et al. Schistosomiasis in European travelers and migrants: Analysis of 14 years TropNet surveillance data. Am. J. Trop Med. Hyg. 2017, 97, 567-574. [CrossRef] [PubMed]

4. Hatz, C.F.R. Schistosomiasis: An underestimated problem in industrialized countries? J. Travel Med. 2005, 12, 1-2. [CrossRef]

5. Wang, S.; Spear, R.C. Exposure versus Susceptibility as Alternative Bases for New Approaches to Surveillance for Schistosoma japonicum in Low Transmission Environments. PLoS Negl. Trop. Dis. 2016, 10, e0004425. [CrossRef]

6. Boissier, J.; Grech-Angelini, S.; Webster, B.L.; Allienne, J.-F.; Huyse, T.; Mas-Coma, S.; Toulza, E.; Barré-Cardi, H.; Rollinson, D.; Kincaid-Smith, J.; et al. Outbreak of urogenital schistosomiasis in Corsica (France): An epidemiological case study. Lancet Infect. Dis. 2016, 16, 971-979. [CrossRef] 
7. Mulero, S.; Rey, O.; Arancibia, N.; Mas-Coma, S.; Boissier, J. Persistent establishment of a tropical disease in Europe: The preadaptation of schistosomes to overwinter. Parasit. Vectors 2019, 12, 379. [CrossRef] [PubMed]

8. Oleaga, A.; Rey, O.; Polack, B.; Grech-Angelini, S.; Quilichini, Y.; Pérez-Sánchez, R.; Boireau, P.; Mulero, S.; Brunet, A.; Rognon, A.; et al. Epidemiological surveillance of schistosomiasis outbreak in Corsica (France): Are animal reservoir hosts implicated in local transmission? PLoS Negl. Trop. Dis. 2019, 13, e0007543. [CrossRef] [PubMed]

9. Léger, E.; Borlase, A.; Fall, C.B.; Diouf, N.D.; Diop, S.D.; Yasenev, L.; Catalano, S.; Thiam, C.T.; Ndiaye, A.; Emery, A.; et al. Prevalence and distribution of schistosomiasis in human, livestock, and snail populations in northern Senegal: A One Health epidemiological study of a multi-host system. Lancet Planet. Health 2020, 4, e330-e342. [CrossRef]

10. McManus, D.P.; Dunne, D.W.; Sacko, M.; Utzinger, J.; Vennervald, B.J.; Zhou, X.-N. Schistosomiasis. Nat. Rev. Dis. Primers 2018, 4, 13. [CrossRef] [PubMed]

11. Cheever, A.W.; Mosimann, J.E.; Deb, S.; Cheever, E.A.; Duvall, R.H. Natural history of Schistosoma mansoni infection in mice: Egg production, egg passage in the feces, and contribution of host and parasite death to changes in worm numbers. Am. J. Trop. Med. Hyg. 1994, 50, 269-280. [CrossRef]

12. Colley, D.G.; Bustinduy, A.L.; Secor, W.E.; King, C.H. Human schistosomiasis. Lancet 2014, 383, 2253-2264. [CrossRef]

13. Chabasse, D.; Bertrand, G.; Leroux, J.P.; Gauthey, N.; Hocquet, P. Bilharziose à Schistosoma mansoni évolutive découverte 37 ans après l'infestation. Bull. Soc. Pathol. Exot. Filiales 1985, 78, 643-647. [PubMed]

14. Grevelding, C.G. Schistosoma. Curr. Biol. 2004, 14, R545. [CrossRef]

15. Costain, A.H.; MacDonald, A.S.; Smits, H.H. Schistosome egg migration: Mechanisms, pathogenesis and host immune responses Front. Immunol. 2018, 9, 3042. [CrossRef]

16. Howley, P.M. Gordon Wilson Lecture: Infectious Disease Causes of Cancer: Opportunities for Prevention and Treatment. Trans. Am. Clin. Climatol. Assoc. 2015, 126, 117-132. [PubMed]

17. Nair, U.; Bartsch, H.; Nair, J. Lipid peroxidation-induced DNA damage in cancer-prone inflammatory diseases: A review of published adduct types and levels in humans. Free Radic. Biol. Med. 2007, 43, 1109-1120. [CrossRef]

18. WHO Globocan. 2020. Available online: https://gco.iarc.fr/today/data/factsheets/cancers/39-All-cancers-fact-sheet.pdf (accessed on 20 May 2021).

19. de Martel, C.; Ferlay, J.; Franceschi, S.; Vignat, J.; Bray, F.; Forman, D.; Plummer, M. Global burden of cancers attributable to infections in 2008: A review and synthetic analysis. Lancet Oncol. 2012, 13, 607-615. [CrossRef]

20. Van Tong, H.; Brindley, P.J.; Meyer, C.G.; Velavan, T.P. Parasite infection, carcinogenesis and human malignancy. EBioMedicine 2017, 15, 12-23. [CrossRef]

21. Shindo, K. Significance of Schistosomiasis japonica in the development of cancer of the large intestine: Report of a case and review of the literature. Dis. Colon Rectum 1976, 19, 460-469. [CrossRef] [PubMed]

22. El-Gazayerli, M.M.; Abdel-Aziz, A.S. On Bilharziasis and Male Breast Cancer in Egypt: A Preliminary Report and Review of the Literature. Br. J. Cancer 1963, 17, 566-571. [CrossRef]

23. Afifi, M.A. Bilharzial Cancer: Radiological Diagnosis and Treatment, 1st ed.; H. K. Lewis \& Co., Ltd.: London, UK, 1948.

24. Biological Agents. Volume 100 B. A review of human carcinogens. IARC Monogr. Eval. Carcinog. Risks Hum. $2012,100,1-441$.

25. Gouveia, M.J.; Pakharukova, M.Y.; Laha, T.; Sripa, B.; Maksimova, G.A.; Rinaldi, G.; Brindley, P.J.; Mordvinov, V.A.; Amaro, T.; Santos, L.L.; et al. Infection with Opisthorchis felineus induces intraepithelial neoplasia of the biliary tract in a rodent model. Carcinogenesis 2017, 38, 929-937. [CrossRef]

26. Pakharukova, M.Y.; Correia da Costa, J.M.; Mordvinov, V.A. The liver fluke Opisthorchis felineus as a group III or group I carcinogen. 4open 2019, 2, 23. [CrossRef]

27. Hsieh, M.H.; Brotherton, J.M.L.; Siddiqui, A.A. Hepatitis B Vaccines and HPV Vaccines Have Been Hailed as Major Public Health Achievements in Preventing Cancer-Could a Schistosomiasis Vaccine be the Third? PLoS Negl. Trop. Dis. 2015, 9, e0003598. [CrossRef] [PubMed]

28. Brindley, P.J.; Costa, J.M.C.d.; Sripa, B. Why does infection with some helminths cause cancer? Trends Cancer 2015, 1, 174-182. [CrossRef] [PubMed]

29. Gouveia, M.J.; Brindley, P.J.; Rinaldi, G.; Gärtner, F.; da Costa, J.M.C.; Vale, N. Infection with carcinogenic helminth parasites and its production of metabolites induces the formation of DNA-adducts. Infect. Agents Cancer 2019, 14, 41. [CrossRef]

30. Cardoso, R.; Lacerda, P.C.; Costa, P.P.; Machado, A.; Carvalho, A.; Bordalo, A.; Fernandes, R.; Soares, R.; Richter, J.; Alves, H.; et al. Estrogen Metabolism-Associated CYP2D6 and IL6-174G/C Polymorphisms in Schistosoma haematobium Infection. Int. J. Mol. Sci. 2017, 18, 2560. [CrossRef] [PubMed]

31. Botelho, M.C.; Alves, H.; Richter, J. Estrogen catechols detection as biomarkers in schistosomiasis induced cancer and infertility. Lett. Drug Des. Discov. 2017, 14, 135-138. [CrossRef] [PubMed]

32. El-Tonsy, M.M.; Hussein, H.M.; Helal, T.E.-S.; Tawfik, R.A.; Koriem, K.M.; Hussein, H.M. Human Schistosomiasis mansoni associated with hepatocellular carcinoma in Egypt: Current perspective. J. Parasit. Dis. 2016, 40, 976-980. [CrossRef]

33. Toda, K.S.; Kikuchi, L.; Chagas, A.L.; Tanigawa, R.Y.; Paranagua-Vezozzo, D.C.; Pfiffer, T.; Rocha, M.d.S.; Alves, V.A.F.; Carrilho, F.J. Hepatocellular carcinoma related to Schistosoma mansoni infection: Case series and Literature Review. J. Clin. Trans. Hep. 2015, 3, 260-264. [CrossRef]

34. Abruzzi, A.; Fried, B.; Alikhan, S.B. Coinfection of Schistosoma species with hepatitis B or hepatitis C viruses. Adv. Parasitol 2016, 91, 111-231. [CrossRef] 
35. Abdel-Rahim, A.Y. Parasitic infections and hepatic neoplasia. Dig. Dis. 2001, 19, 288-291. [CrossRef]

36. Bahgat, M.M. Interaction between the Neglected Tropical Disease Human Schistosomiasis and HCV Infection in Egypt: A Puzzling Relationship. J. Clin. Transl. Hepatol. 2014, 2, 134-139. [CrossRef] [PubMed]

37. Gentile, J.M.; Gentile, G.J. Implications for the involvement of the immune system in parasite-associated cancers. Mutat. Res. 1994, 305, 315-320. [CrossRef]

38. Kamal, S.; Madwar, M.; Bianchi, L.; Tawil, A.E.; Fawzy, R.; Peters, T.; Rasenack, J.W. Clinical, virological and histopathological features: Long-term follow-up in patients with chronic hepatitis C co-infected with S. mansoni. Liver 2000, 20, 281-289. [CrossRef]

39. Khurana, S.; Dubey, M.L.; Malla, N. Association of parasitic infections and cancers. Indian J. Med. Microbiol. 2005, 23, 7479. [CrossRef]

40. Palumbo, E. Association between schistosomiasis and cancer. Infect. Dis. Clin. Pract. 2007, 15, 145-148. [CrossRef]

41. Shaker, Y.; Samy, N.; Ashour, E. Hepatobiliary Schistosomiasis. J. Clin. Transl. Hepatol. 2014, 2, 212-216. [CrossRef] [PubMed]

42. Strickland, G.T. Liver disease in Egypt: Hepatitis C superseded schistosomiasis as a result of iatrogenic and biological factors. Hepatology 2006, 43, 915-922. [CrossRef] [PubMed]

43. Salim, O.E.H.; Hamid, H.K.S.; Mekki, S.O.; Suleiman, S.H.; Ibrahim, S.Z. Colorectal carcinoma associated with schistosomiasis: A possible causal relationship. World J. Surg. Oncol. 2010, 8, 68. [CrossRef] [PubMed]

44. Ameh, E.A.; Nmadu, P.T. Colorectal adenocarcinoma in children and adolescents: A report of 8 patients from Zaria, Nigeria. West. Afr. J. Med. 2000, 19, 273-276.

45. Herman, A.M.; Kishe, A.; Babu, H.; Shilanaiman, H.; Tarmohamed, M.; Lodhia, J.; Amsi, P.; Pyuza, J.; Mremi, A.; Mwasamwaja, A.; et al. Colorectal cancer in a patient with intestinal schistosomiasis: A case report from Kilimanjaro Christian Medical Center Northern Zone Tanzania. World J. Surg. Oncol. 2017, 15, 146. [CrossRef] [PubMed]

46. Madbouly, K.M.; Senagore, A.J.; Mukerjee, A.; Hussien, A.M.; Shehata, M.A.; Navine, P.; Delaney, C.P.; Fazio, V.W. Colorectal cancer in a population with endemic Schistosoma mansoni: Is this an at-risk population? Int. J. Colorectal Dis. 2007, 22, 175-181. [CrossRef] [PubMed]

47. Soliman, A.S.; Bondy, M.L.; Levin, B.; Hamza, M.R.; Ismail, K.; Ismail, S.; Hammam, H.M.; el-Hattab, O.H.; Kamal, S.M.; Soliman, A.G.; et al. Colorectal cancer in Egyptian patients under 40 years of age. Int. J. Cancer 1997, 71, 26-30. [CrossRef]

48. Zalata, K.R.; Nasif, W.A.; Ming, S.-C.; Lotfy, M.; Nada, N.A.; El-Hak, N.G.; Leech, S.H. p53, Bcl-2 and C-Myc expressions in colorectal carcinoma associated with schistosomiasis in Egypt. Cell Oncol. 2005, 27, 245-253. [CrossRef] [PubMed]

49. Kiremit, M.C.; Cakir, A.; Arslan, F.; Ormeci, T.; Erkurt, B.; Albayrak, S. The bladder carcinoma secondary to Schistosoma mansoni infection: A case report with review of the literature. Int. J. Surg. Case Rep. 2015, 13, 76-78. [CrossRef]

50. Basílio-de-Oliveira, C.A.; Aquino, A.; Simon, E.F.; Eyer-Silva, W.A. Concomitant prostatic schistosomiasis and adenocarcinoma: Case report and review. Braz J. Infect. Dis. 2002, 6, 45-49. [CrossRef]

51. de Andrade, D.R.; Ishioka, S.; Câmara-Lopes, L.H.; Meira, J.A. Associação da esquistossomose mansônica hepatoesplênica e linfoma histiocítico. Arq. Gastroenterol. 1982, 19, 77-80.

52. Andrade, Z.A.; Abreu, W.N. Follicular lymphoma of the spleen in patients with hepatosplenic Schistosomiasis mansoni. Am. J. Trop. Med. Hyg. 1971, 20, 237-243. [CrossRef]

53. Russell, H.J.; Penney, J.M.S.; Linder, C.; Joekes, E.C.; Bustinduy, A.L.; Stothard, J.R.; Rakotomampianina, D.A.L.; Andriamasy, E.H.; Mahary, L.R.; Ranjanoro, E.P.; et al. A cross-sectional study of periportal fibrosis and Schistosoma mansoni infection among school-aged children in a hard-to-reach area of Madagascar. Trans. R. Soc. Trop. Med. Hyg. 2020, 114, 315-322. [CrossRef]

54. Roderfeld, M. Matrix metalloproteinase functions in hepatic injury and fibrosis. Matrix Biol. 2018, 68-69, 452-462. [CrossRef]

55. Schuppan, D.; Afdhal, N.H. Liver cirrhosis. Lancet 2008, 371, 838-851. [CrossRef]

56. Roeb, E. Matrix metalloproteinases and liver fibrosis (translational aspects). Matrix Biol. 2018, 68-69, 463-473. [CrossRef]

57. Puche, J.E.; Saiman, Y.; Friedman, S.L. Hepatic stellate cells and liver fibrosis. Compr. Physiol. 2013, 3, 1473-1492. [CrossRef]

58. Bray, F.; Ferlay, J.; Soerjomataram, I.; Rebecca, L.S.; Torre, L.A.; Jemal, A. Global cancer statistics 2018: GLOBOCAN estimates of incidence and mortality worldwide for 36 cancers in 185 countries. CA Cancer J. Clin. 2018, 68, 394-424. [CrossRef] [PubMed]

59. Luedde, T.; Schwabe, R.F. NF-кB in the liver-linking injury, fibrosis and hepatocellular carcinoma. Nat. Rev. Gastroenterol. Hepatol. 2011, 8, 108-118. [CrossRef] [PubMed]

60. Bruix, J.; Sherman, M. Management of hepatocellular carcinoma: An update. Hepatology 2011, 53, 1020-1022. [CrossRef] [PubMed]

61. Churin, Y.; Roderfeld, M.; Roeb, E. Hepatitis B virus large surface protein: Function and fame. Hepatobiliary Surg. Nutr. 2015, 4, 1-10. [CrossRef]

62. Roeb, E.; Steffen, H.M.; Bantel, H.; Baumann, U.; Canbay, A.; Demir, M.; Drebber, U.; Geier, A.; Hampe, J.; Hellerbrand, C.; et al. S2k-Leitlinie nicht alkoholische Fettlebererkrankungen. Z. Gastroenterol. 2015, 53, 668-723. [CrossRef]

63. Roeb, E.; Geier, A. Nichtalkoholische Steatohepatitis (NASH)-aktuelle Behandlungsempfehlungen und zukünftige Entwicklungen. Z. Gastroenterol. 2019, 57, 508-517. [CrossRef]

64. Starley, B.Q.; Calcagno, C.J.; Harrison, S.A. Nonalcoholic fatty liver disease and hepatocellular carcinoma: A weighty connection. Hepatology 2010, 51, 1820-1832. [CrossRef]

65. Anstee, Q.M.; Reeves, H.L.; Kotsiliti, E.; Govaere, O.; Heikenwalder, M. From NASH to HCC: Current concepts and future challenges. Nat. Rev. Gastroenterol. Hepatol. 2019, 16, 411-428. [CrossRef] [PubMed]

66. Dudek, M.; Pfister, D.; Donakonda, S.; Filpe, P.; Schneider, A.; Laschinger, M.; Hartmann, D.; Hüser, N.; Meiser, P.; Bayerl, F.; et al. Auto-aggressive CXCR6+ CD8 T cells cause liver immune pathology in NASH. Nature 2021, 592, 444-449. [CrossRef] [PubMed] 
67. Miura, N.; Horikawa, I.; Nishimoto, A.; Ohmura, H.; Ito, H.; Hirohashi, S.; Shay, J.W.; Oshimura, M. Progressive telomere shortening and telomerase reactivation during hepatocellular carcinogenesis. Cancer Genet. Cytogenet. 1997, 93, 56-62. [CrossRef]

68. Marra, M.; Sordelli, I.M.; Lombardi, A.; Lamberti, M.; Tarantino, L.; Giudice, A.; Stiuso, P.; Abbruzzese, A.; Sperlongano, R.; Accardo, M.; et al. Molecular targets and oxidative stress biomarkers in hepatocellular carcinoma: An overview. J. Transl. Med. 2011, 9, 171. [CrossRef]

69. Pfister, D.; Núñez, N.G.; Pinyol, R.; Govaere, O.; Pinter, M.; Szydlowska, M.; Gupta, R.; Qiu, M.; Deczkowska, A.; Weiner, A.; et al. NASH limits anti-tumour surveillance in immunotherapy-treated HCC. Nature 2021, 592, 450-456. [CrossRef]

70. El-Serag, H.B.; Rudolph, K.L. Hepatocellular carcinoma: Epidemiology and molecular carcinogenesis. Gastroenterology 2007, 132, 2557-2576. [CrossRef]

71. Gasim, G.I.; Bella, A.; Adam, I. Schistosomiasis, hepatitis B and hepatitis C co-infection. Virol. J. 2015, 12, 19. [CrossRef]

72. el-Kady, I.M.; el-Masry, S.A.; Badra, G.; Halafawy, K.A. Different cytokine patterns in patients coinfected with hepatitis C virus and Schistosoma mansoni. Egypt. J. Immunol. 2004, 11, 23-29. [PubMed]

73. Han, Y.; Liu, D.; Li, L. PD-1/PD-L1 pathway: Current researches in cancer. Am. J. Cancer Res. 2020, 10, 727-742. [PubMed]

74. Smith, P.; Walsh, C.M.; Mangan, N.E.; Fallon, R.E.; Sayers, J.R.; McKenzie, A.N.J.; Fallon, P.G. Schistosoma mansoni worms induce anergy of T cells via selective up-regulation of programmed death ligand 1 on macrophages. J. Immunol. 2004, 173, 1240-1248. [CrossRef] [PubMed]

75. Zhou, S.; Jin, X.; Li, Y.; Li, W.; Chen, X.; Xu, L.; Zhu, J.; Xu, Z.; Zhang, Y.; Liu, F.; et al. Blockade of PD-1 Signaling Enhances Th2 Cell Responses and Aggravates Liver Immunopathology in Mice with Schistosomiasis japonica. PLoS Negl. Trop. Dis. 2016, 10, e0005094. [CrossRef]

76. Hernandez-Gea, V.; Toffanin, S.; Friedman, S.L.; Llovet, J.M. Role of the microenvironment in the pathogenesis and treatment of hepatocellular carcinoma. Gastroenterology 2013, 144, 512-527. [CrossRef] [PubMed]

77. Zheng, B.; Zhang, J.; Chen, H.; Nie, H.; Miller, H.; Gong, Q.; Liu, C. T Lymphocyte-Mediated Liver Immunopathology of Schistosomiasis. Front. Immunol. 2020, 11, 61. [CrossRef] [PubMed]

78. Almeida, C.A.; Goes, A.M. Human peripheral blood mononuclear cells stimulated by Schistosoma mansoni antigens: Association between protein tyrosine kinases, mitogen-activated protein kinases and cytokine production. Parasitol. Int. 2000, 48, 255-264. [CrossRef]

79. Almeida, C.A.; Romano-Silva, M.A.; Goes, A.M. Inhibition of protein kinases prevents lymphocyte activation by Schistosoma mansoni antigens and reduces in vivo granuloma reaction. Immunol. Lett. 1998, 62, 137-143. [CrossRef]

80. Almeida, C.A.; Leite, M.F.; Goes, A.M. Signal transduction events in human peripheral blood mononuclear cells stimulated by Schistosoma mansoni antigens. Hum. Immunol. 2001, 62, 1159-1166. [CrossRef]

81. Oliveira-Prado, R.; Caldas, I.R.; Teixeira-Carvalho, A.; Andrade, M.V.; Fares, R.C.G.; Portugal, L.M.; Gazzinelli, A.; CorrêaOliveira, R.; Cunha-Melo, J.R. Cytokine profile, proliferation and phosphorylation of ERK1/2 and Akt in circulating mononuclear cells from individuals during the chronic intestinal phase of Schistosomiasis mansoni infection. BMC Infect. Dis. 2012, 12, 380. [CrossRef] [PubMed]

82. Yegorov, S.; Joag, V.; Galiwango, R.M.; Good, S.V.; Mpendo, J.; Tannich, E.; Boggild, A.K.; Kiwanuka, N.; Bagaya, B.S.; Kaul, R. Schistosoma mansoni treatment reduces HIV entry into cervical CD4+ T cells and induces IFN-I pathways. Nat. Commun. 2019, 10, 2296. [CrossRef]

83. Chaudhary, B.; Elkord, E. Regulatory T Cells in the Tumor Microenvironment and Cancer Progression: Role and Therapeutic Targeting. Vaccines 2016, 4, 28. [CrossRef]

84. Li, Z.; Wu, T.; Zheng, B.; Chen, L. Individualized precision treatment: Targeting TAM in HCC. Cancer Lett. 2019, 458, 86-91. [CrossRef]

85. Meevissen, M.H.J.; Driessen, N.N.; Smits, H.H.; Versteegh, R.; van Vliet, S.J.; van Kooyk, Y.; Schramm, G.; Deelder, A.M.; Haas, H.; Yazdanbakhsh, M.; et al. Specific glycan elements determine differential binding of individual egg glycoproteins of the human parasite Schistosoma mansoni by host C-type lectin receptors. Int. J. Parasitol. 2012, 42, 269-277. [CrossRef]

86. Abdulla, M.-H.; Lim, K.-C.; McKerrow, J.H.; Caffrey, C.R. Proteomic identification of IPSE/alpha-1 as a major hepatotoxin secreted by Schistosoma mansoni eggs. PLoS. Negl. Trop. Dis. 2011, 5, e1368. [CrossRef]

87. Everts, B.; Hussaarts, L.; Driessen, N.N.; Meevissen, M.H.J.; Schramm, G.; van der Ham, A.J.; van der Hoeven, B.; Scholzen, T.; Burgdorf, S.; Mohrs, M.; et al. Schistosome-derived omega-1 drives Th2 polarization by suppressing protein synthesis following internalization by the mannose receptor. J. Exp. Med. 2012, 209, 1753-1767. [CrossRef]

88. Knuhr, K.; Langhans, K.; Nyenhuis, S.; Viertmann, K.; Kildemoes, A.M.O.; Doenhoff, M.J.; Haas, H.; Schramm, G. Schistosoma mansoni Egg-Released IPSE/alpha-1 Dampens Inflammatory Cytokine Responses via Basophil Interleukin (IL)-4 and IL-13. Front. Immunol. 2018, 9, 2293. [CrossRef]

89. Kaur, I.; Schramm, G.; Everts, B.; Scholzen, T.; Kindle, K.B.; Beetz, C.; Montiel-Duarte, C.; Blindow, S.; Jones, A.T.; Haas, H.; et al. Interleukin-4-Inducing Principle from Schistosoma mansoni Eggs Contains a Functional C-Terminal Nuclear Localization Signal Necessary for Nuclear Translocation in Mammalian Cells but Not for Its Uptake. Infect. Immun. 2011, 79, 1779-1788. [CrossRef]

90. Pennington, L.F.; Alouffi, A.; Mbanefo, E.C.; Ray, D.; Heery, D.M.; Jardetzky, T.S.; Hsieh, M.H.; Falcone, F.H. H-IPSE is a pathogen-secreted host nucleus infiltrating protein (infiltrin) expressed exclusively by the Schistosoma haematobium egg stage. Infec. Immun. 2017, 85, e00301-17. [CrossRef] 
91. Fahel, J.S.; Macedo, G.C.; Pinheiro, C.S.; Caliari, M.V.; Oliveira, S.C. IPSE/alpha-1 of Schistosoma mansoni egg induces enlargement of granuloma but does not alter Th2 balance after infection. Parasite Immunol. 2010, 32, 345-353. [CrossRef] [PubMed]

92. Sica, A.; Mantovani, A. Macrophage plasticity and polarization: In vivo veritas. J. Clin. Investig. 2012, 122, 787-795. [CrossRef]

93. Mbanefo, E.C.; Le, L.; Pennington, L.F.; Hsieh, Y.-J.; Odegaard, J.I.; Lapira, K.; Jardetzky, T.S.; Falcone, F.H.; Hsieh, M.H. IPSE, a urogenital parasite-derived immunomodulatory molecule, suppresses bladder pathogenesis and anti-microbial peptide gene expression in bacterial urinary tract infection. Parasit. Vectors 2020, 13, 615. [CrossRef] [PubMed]

94. Steinfelder, S.; Andersen, J.F.; Cannons, J.L.; Feng, C.G.; Joshi, M.; Dwyer, D.; Caspar, P.; Schwartzberg, P.L.; Sher, A.; Jankovic, D. The major component in schistosome eggs responsible for conditioning dendritic cells for Th2 polarization is a T2 ribonuclease (omega-1). J. Exp. Med. 2009, 206, 1681-1690. [CrossRef]

95. Oliveira, K.C.; Cardoso, R.; Dos Santos, A.C.; Fernandes, R.; Botelho, M.C. Imbalance of Steroid Hormones in Hamsters Infected with Schistosoma mansoni. Endocr. Metab. Immune Disord. Drug Targets 2019, 19, 1122-1126. [CrossRef]

96. Stadecker, M.J.; Asahi, H.; Finger, E.; Hernandez, H.J.; Rutitzky, L.I.; Sun, J. The immunobiology of Th1 polarization in highpathology schistosomiasis. Immunol. Rev. 2004, 201, 168-179. [CrossRef]

97. Mantovani, A.; Allavena, P.; Sica, A.; Balkwill, F. Cancer-related inflammation. Nature 2008, 454, 436-444. [CrossRef]

98. Budhu, A.; Forgues, M.; Ye, Q.-H.; Jia, H.-L.; He, P.; Zanetti, K.A.; Kammula, U.S.; Chen, Y.; Qin, L.-X.; Tang, Z.-Y.; et al. Prediction of venous metastases, recurrence, and prognosis in hepatocellular carcinoma based on a unique immune response signature of the liver microenvironment. Cancer Cell 2006, 10, 99-111. [CrossRef] [PubMed]

99. Shao, Y.; Lo, C.M.; Ling, C.C.; Liu, X.B.; Ng, K.T.-P.; Chu, A.C.Y.; Ma, Y.Y.; Li, C.X.; Fan, S.T.; Man, K. Regulatory B cells accelerate hepatocellular carcinoma progression via CD40/CD154 signaling pathway. Cancer Lett. 2014, 355, 264-272. [CrossRef] [PubMed]

100. Haeberlein, S.; Obieglo, K.; Ozir-Fazalalikhan, A.; Chayé, M.A.M.; Veninga, H.; van der Vlugt, L.E.P.M.; Voskamp, A.; Boon, L.; den Haan, J.M.M.; Westerhof, L.B.; et al. Schistosome egg antigens, including the glycoprotein IPSE/alpha-1, trigger the development of regulatory B cells. PLoS Pathog. 2017, 13, e1006539. [CrossRef]

101. Lurje, I.; Hammerich, L.; Tacke, F. Dendritic Cell and T Cell Crosstalk in Liver Fibrogenesis and Hepatocarcinogenesis: Implications for Prevention and Therapy of Liver Cancer. Int. J. Mol. Sci. 2020, 21, 7378. [CrossRef] [PubMed]

102. Shen, X.; Li, N.; Li, H.; Zhang, T.; Wang, F.; Li, Q. Increased prevalence of regulatory T cells in the tumor microenvironment and its correlation with TNM stage of hepatocellular carcinoma. J. Cancer Res. Clin. Oncol. 2010, 136, 1745-1754. [CrossRef] [PubMed]

103. Cooke, A.; Tonks, P.; Jones, F.M.; O'Shea, H.; Hutchings, P.; Fulford, A.J.; Dunne, D.W. Infection with Schistosoma mansoni prevents insulin dependent diabetes mellitus in non-obese diabetic mice. Parasite Immunol. 1999, 21, 169-176. [CrossRef]

104. Xu, Z.-P.; Chang, H.; Ni, Y.-Y.; Li, C.; Chen, L.; Hou, M.; Ji, M.-J. Schistosoma japonicum infection causes a reprogramming of glycolipid metabolism in the liver. Parasit. Vectors 2019, 12, 388. [CrossRef]

105. Weglage, J.; Wolters, F.; Hehr, L.; Lichtenberger, J.; Wulz, C.; Hempel, F.; Baier, A.; Quack, T.; Köhler, K.; Longerich, T.; et al. Schistosoma mansoni eggs induce Wnt/ $\beta$-catenin signaling and activate the protooncogene c-Jun in human and hamster colon. Sci. Rep. 2020, 10, 2492. [CrossRef] [PubMed]

106. Roderfeld, M.; Padem, S.; Lichtenberger, J.; Quack, T.; Weiskirchen, R.; Longerich, T.; Schramm, G.; Churin, Y.; Irungbam, K.; Tschuschner, A.; et al. Schistosoma mansoni egg secreted antigens activate HCC-associated transcription factors c-Jun and STAT3 in hamster and human hepatocytes. Hepatology 2020, 72, 626-641. [CrossRef]

107. Osada, Y.; Shimizu, S.; Kumagai, T.; Yamada, S.; Kanazawa, T. Schistosoma mansoni infection reduces severity of collagen-induced arthritis via down-regulation of pro-inflammatory mediators. Int. J. Parasitol. 2009, 39, 457-464. [CrossRef] [PubMed]

108. Song, X.; Shen, J.; Wen, H.; Zhong, Z.; Luo, Q.; Chu, D.; Qi, Y.; Xu, Y.; Wei, W. Impact of Schistosoma japonicum infection on collagen-induced arthritis in DBA/1 mice: A murine model of human rheumatoid arthritis. PLoS ONE 2011, 6, e23453. [CrossRef]

109. Driss, V.; El Nady, M.; Delbeke, M.; Rousseaux, C.; Dubuquoy, C.; Sarazin, A.; Gatault, S.; Dendooven, A.; Riveau, G.; Colombel, J.F.; et al. The schistosome glutathione S-transferase P28GST, a unique helminth protein, prevents intestinal inflammation in experimental colitis through a Th2-type response with mucosal eosinophils. Mucosal Immunol. 2016, 9, 322-335. [CrossRef] [PubMed]

110. Floudas, A.; Aviello, G.; Schwartz, C.; Jeffery, I.B.; O’Toole, P.W.; Fallon, P.G. Schistosoma mansoni worm infection regulates the intestinal microbiota and susceptibility to colitis. Infect. Immun. 2019, 87, e00275. [CrossRef]

111. Wang, L.; Xie, H.; Xu, L.; Liao, Q.; Wan, S.; Yu, Z.; Lin, D.; Zhang, B.; Lv, Z.; Wu, Z.; et al. rSj16 Protects against DSS-Induced Colitis by Inhibiting the PPAR- $\alpha$ Signaling Pathway. Theranostics 2017, 7, 3446-3460. [CrossRef] [PubMed]

112. Yan, K.; Wang, B.; Zhou, H.; Luo, Q.; Shen, J.; Xu, Y.; Zhong, Z. Amelioration of type 1 diabetes by recombinant fructose1,6-bisphosphate aldolase and cystatin derived from Schistosoma japonicum in a murine model. Parasitol. Res. 2020, 119, 203-214. [CrossRef]

113. Li, H.; Wang, S.; Zhan, B.; He, W.; Chu, L.; Qiu, D.; Li, N.; Wan, Y.; Zhang, H.; Chen, X.; et al. Therapeutic effect of Schistosoma japonicum cystatin on bacterial sepsis in mice. Parasit. Vectors 2017, 10, 222. [CrossRef]

114. He, G.; Yu, G.-Y.; Temkin, V.; Ogata, H.; Kuntzen, C.; Sakurai, T.; Sieghart, W.; Peck-Radosavljevic, M.; Leffert, H.L.; Karin, M. Hepatocyte IKKbeta/NF-kappaB inhibits tumor promotion and progression by preventing oxidative stress-driven STAT3 activation. Cancer Cell 2010, 17, 286-297. [CrossRef]

115. Eissa, M.M.; Mostafa, D.K.; Ghazy, A.A.; El Azzouni, M.Z.; Boulos, L.M.; Younis, L.K. Anti-Arthritic Activity of Schistosoma mansoni and Trichinella spiralis Derived-Antigens in Adjuvant Arthritis in Rats: Role of FOXP3+ Treg Cells. PLoS ONE 2016, 11, e0165916. [CrossRef] [PubMed] 
116. Hasby, E.A.; Hasby Saad, M.A.; Shohieb, Z.; El Noby, K. FoxP3+ T regulatory cells and immunomodulation after Schistosoma mansoni egg antigen immunization in experimental model of inflammatory bowel disease. Cell Immunol. 2015, 295, 67-76. [CrossRef]

117. Cleenewerk, L.; Garssen, J.; Hogenkamp, A. Clinical Use of Schistosoma mansoni Antigens as Novel Immunotherapies for Autoimmune Disorders. Front. Immunol. 2020, 11, 1821. [CrossRef]

118. Osada, Y.; Fujiyama, T.; Kamimura, N.; Kaji, T.; Nakae, S.; Sudo, K.; Ishiwata, K.; Kanazawa, T. Dual genetic absence of STAT6 and IL-10 does not abrogate anti-hyperglycemic effects of Schistosoma mansoni in streptozotocin-treated diabetic mice. Exp. Parasitol. 2017, 177, 1-12. [CrossRef]

119. Hussaarts, L.; García-Tardón, N.; van Beek, L.; Heemskerk, M.M.; Haeberlein, S.; van der Zon, G.C.; Ozir-Fazalalikhan, A.; Berbée, J.F.P.; van Willems Dijk, K.; van Harmelen, V.; et al. Chronic helminth infection and helminth-derived egg antigens promote adipose tissue M2 macrophages and improve insulin sensitivity in obese mice. FASEB J. 2015, 29, 3027-3039. [CrossRef]

120. Tang, C.-L.; Yu, X.-H.; Li, Y.; Zhang, R.-H.; Xie, J.; Liu, Z.-M. Schistosoma japonicum Soluble Egg Antigen Protects against Type 2 Diabetes in Leprdb/db Mice by Enhancing Regulatory T Cells and Th2 Cytokines. Front. Immunol. 2019, 10, 271. [CrossRef]

121. Tang, H.; Liang, Y.-B.; Chen, Z.-B.; Du, L.-L.; Zeng, L.-J.; Wu, J.-G.; Yang, W.; Liang, H.-P.; Ma, Z.-F. Soluble Egg Antigen Activates M2 Macrophages via the STAT6 and PI3K Pathways, and Schistosoma Japonicum Alternatively Activates Macrophage Polarization to Improve the Survival Rate of Septic Mice. J. Cell Biochem. 2017, 118, 4230-4239. [CrossRef]

122. El-Tonsy, M.M.; Hussein, H.M.; Helal, T.; Tawfik, R.A.; Koriem, K.M.; Hussein, H.M. Schistosoma mansoni infection: Is it a risk factor for development of hepatocellular carcinoma? Acta Trop. 2013, 128, 542-547. [CrossRef]

123. He, G.; Dhar, D.; Nakagawa, H.; Font-Burgada, J.; Ogata, H.; Jiang, Y.; Shalapour, S.; Seki, E.; Yost, S.E.; Jepsen, K.; et al. Identification of liver cancer progenitors whose malignant progression depends on autocrine IL-6 signaling. Cell 2013, 155, 384-396. [CrossRef]

124. He, G.; Karin, M. NF-кB and STAT3 - key players in liver inflammation and cancer. Cell Res. 2011, 21, 159-168. [CrossRef]

125. Verzella, D.; Pescatore, A.; Capece, D.; Vecchiotti, D.; Ursini, M.V.; Franzoso, G.; Alesse, E.; Zazzeroni, F. Life, death, and autophagy in cancer: NF-кB turns up everywhere. Cell Death Dis. 2020, 11, 210. [CrossRef]

126. Chen, T.T.W.; Cheng, P.C.; Chang, K.C.; Cao, J.P.; Feng, J.L.; Chen, C.C.; Lam, H.Y.P.; Peng, S.Y. Activation of the NLRP3 and AIM2 inflammasomes in a mouse model of Schistosoma mansoni infection. J. Helminthol. 2019, 94, e72. [CrossRef]

127. Vennervald, B.J.; Polman, K. Helminths and malignancy. Parasite Immunol. 2009, 31, 686-696. [CrossRef]

128. de Oliveira, R.B.; Senger, M.R.; Vasques, L.M.; Gasparotto, J.; dos Santos, J.P.A.; Pasquali, M.A.d.B.; Moreira, J.C.F.; Silva, F.P.; Gelain, D.P. Schistosoma mansoni infection causes oxidative stress and alters receptor for advanced glycation endproduct (RAGE) and tau levels in multiple organs in mice. Int. J. Parasitol. 2013, 43, 371-379. [CrossRef] [PubMed]

129. Habib, S.L.; Said, B.; Awad, A.T.; Mostafa, M.H.; Shank, R.C. Novel adenine adducts, N7-guanine-AFB1 adducts, and p53 mutations in patients with schistosomiasis and aflatoxin exposure. Cancer Detect. Prev. 2006, 30, 491-498. [CrossRef]

130. Jusakul, A.; Cutcutache, I.; Yong, C.H.; Lim, J.Q.; Huang, M.N.; Padmanabhan, N.; Nellore, V.; Kongpetch, S.; Ng, A.W.T.; Ng, L.M.; et al. Whole-Genome and Epigenomic Landscapes of Etiologically Distinct Subtypes of Cholangiocarcinoma. Cancer Discov. 2017, 7, 1116-1135. [CrossRef]

131. Bromberg, J.F.; Wrzeszczynska, M.H.; Devgan, G.; Zhao, Y.; Pestell, R.G.; Albanese, C.; Darnell, J.E. Stat3 as an oncogene. Cell 1999, 98, 295-303. [CrossRef]

132. Wang, T.; Niu, G.; Kortylewski, M.; Burdelya, L.; Shain, K.; Zhang, S.; Bhattacharya, R.; Gabrilovich, D.; Heller, R.; Coppola, D.; et al. Regulation of the innate and adaptive immune responses by Stat-3 signaling in tumor cells. Nat. Med. 2004, 10, 48-54. [CrossRef]

133. Fuest, M.; Willim, K.; MacNelly, S.; Fellner, N.; Resch, G.P.; Blum, H.E.; Hasselblatt, P. The transcription factor c-Jun protects against sustained hepatic endoplasmic reticulum stress thereby promoting hepatocyte survival. Hepatology 2012, 55, 408-418. [CrossRef] [PubMed]

134. Stepniak, E.; Ricci, R.; Eferl, R.; Sumara, G.; Sumara, I.; Rath, M.; Hui, L.; Wagner, E.F. c-Jun/AP-1 controls liver regeneration by repressing p53/p21 and p38 MAPK activity. Genes Dev. 2006, 20, 2306-2314. [CrossRef]

135. Eferl, R.; Ricci, R.; Kenner, L.; Zenz, R.; David, J.-P.; Rath, M.; Wagner, E.F. Liver tumor development. c-Jun antagonizes the proapoptotic activity of p53. Cell 2003, 112, 181-192. [CrossRef]

136. Min, L.; Ji, Y.; Bakiri, L.; Qiu, Z.; Cen, J.; Chen, X.; Chen, L.; Scheuch, H.; Zheng, H.; Qin, L.; et al. Liver cancer initiation is controlled by AP-1 through SIRT6-dependent inhibition of survivin. Nat. Cell Biol. 2012, 14, 1203-1211. [CrossRef]

137. Machida, K.; Tsukamoto, H.; Liu, J.-C.; Han, Y.-P.; Govindarajan, S.; Lai, M.M.C.; Akira, S.; Ou, J.-H.J. c-Jun mediates hepatitis C virus hepatocarcinogenesis through signal transducer and activator of transcription 3 and nitric oxide-dependent impairment of oxidative DNA repair. Hepatology 2010, 52, 480-492. [CrossRef] [PubMed]

138. CHEEVER, A. Hepatic vascular lesions in mice infected with Schistosoma mansoni. Arch. Pathol. 1961, 72, 648-657. [PubMed]

139. Shariati, F.; Pérez-Arellano, J.L.; Carranza, C.; López-Abán, J.; Vicente, B.; Arefi, M.; Muro, A. Evaluation of the role of angiogenic factors in the pathogenesis of schistosomiasis. Exp. Parasitol. 2011, 128, 44-49. [CrossRef]

140. Freedman, D.O.; Ottesen, E.A. Eggs of Schistosoma mansoni stimulate endothelial cell proliferation in vitro. J. Infect. Dis. 1988, 158, 556-562. [CrossRef]

141. Loeffler, D.A.; Lundy, S.K.; Singh, K.P.; Gerard, H.C.; Hudson, A.P.; Boros, D.L. Soluble egg antigens from Schistosoma mansoni induce angiogenesis-related processes by up-regulating vascular endothelial growth factor in human endothelial cells. J. Infect. Dis. 2002, 185, 1650-1656. [CrossRef] [PubMed] 
142. Keum, N.; Giovannucci, E. Global burden of colorectal cancer: Emerging trends, risk factors and prevention strategies. Nat. Rev. Gastroenterol. Hepatol. 2019, 16, 713-732. [CrossRef]

143. Montminy, E.M.; Jang, A.; Conner, M.; Karlitz, J.J. Screening for Colorectal Cancer. Med. Clin. N. Am. 2020, 104, 1023-1036. [CrossRef]

144. Elbaz, T.; Esmat, G. Hepatic and intestinal schistosomiasis: Review. J. Adv. Res. 2013, 4, 445-452. [CrossRef]

145. Mohamed, A.R.; al Karawi, M.; Yasawy, M.I. Schistosomal colonic disease. Gut 1990, 31, 439-442. [CrossRef] [PubMed]

146. Issa, I.; Osman, M.; Aftimos, G. Schistosomiasis manifesting as a colon polyp: A case report. J. Med. Case Rep. 2014, 8, 331. [CrossRef]

147. Jamal, M.; Rayes, O.; Samuel, L.; Tibbetts, R.; Pimentel, J.D. The Brief Case: Benign Rectal Polyp with Schistosoma mansoni. J. Clin. Microbiol. 2017, 55, 992-995. [CrossRef]

148. Raso, P.; Sander, E.M.; Raso, L.A.M.; Andrade Filho, J.d.S. Anal polyp caused by Schistosoma mansoni. Rev. Soc. Bras. Med. Trop. 2013, 46, 252-254. [CrossRef] [PubMed]

149. Ata, A.A.; el-Raziky, S.H.; el-Hawey, A.M.; Rafla, H. A clinicopathological study of schistosomal colonic polyposis and their pathogenesis. J. Egypt. Med. Assoc. 1970, 53, 762-772.

150. Akere, A.; Oluwasola, A.O.; Fakoya, T.O.; Lawan, A. Schistosomiasis presenting as colonic polypoid masses in a nigerian patient. Ann. Ib. Postgrad. Med. 2017, 15, 61-64.

151. Ch'en, M.C.; Hu, J.C.; Chang, P.Y.; Chuang, C.Y.; Ts'ao, P.F.; Chang, S.H.; Wang, F.P.; Ch'en, T.L.; Chou, S.C. Pathogenesis of carcinoma of the colon and rectum in schistosomiasis japonica: A study on 90 cases. Chin. Med. J. 1965, 84, 513-525. [PubMed]

152. el Malatawy, A.; el Habashy, A.; Lechine, N.; Dixon, H.; Davis, A.; Mott, K.E. Selective population chemotherapy among schoolchildren in Beheira governorate: The UNICEF/Arab Republic of Egypt/WHO Schistosomiasis Control Project. Bull. World Health Organ. 1992, 70, 47-56.

153. Ming-Chai, C.; Chi-Yuan, C.; Pei-Yu, C.; Jen-Chun, H. Evolution of colorectal cancer in schistsosomiasis: Transitional mucosal changes adjacent to large intestinal carcinoma in colectomy specimens. Cancer 1980, 46, 1661-1675. [CrossRef]

154. Faust, C.L.; Osakunor, D.N.M.; Downs, J.A.; Kayuni, S.; Stothard, J.R.; Lamberton, P.H.L.; Reinhard-Rupp, J.; Rollinson, D. Schistosomiasis Control: Leave No Age Group Behind. Trends Parasitol. 2020, 36, 582-591. [CrossRef] [PubMed]

155. Kabatereine, N.B.; Kemijumbi, J.; Ouma, J.H.; Kariuki, H.C.; Richter, J.; Kadzo, H.; Madsen, H.; Butterworth, A.E.; Ørnbjerg, N.; Vennervald, B.J. Epidemiology and morbidity of Schistosoma mansoni infection in a fishing community along Lake Albert in Uganda. Trans. R. Soc. Trop. Med. Hyg. 2004, 98, 711-718. [CrossRef] [PubMed]

156. Lin, M.; Hanai, J.; Gui, L. Peanut lectin-binding sites and mucins in benign and malignant colorectal tissues associated with schistomatosis. Histol. Histopathol. 1998, 13, 961-966. [CrossRef]

157. Soliman, A.S.; Bondy, M.L.; El-Badawy, S.A.; Mokhtar, N.; Eissa, S.; Bayoumy, S.; Seifeldin, I.A.; Houlihan, P.S.; Lukish, J.R.; Watanabe, T.; et al. Contrasting molecular pathology of colorectal carcinoma in Egyptian and Western patients. Br. J. Cancer 2001, 85, 1037-1046. [CrossRef] [PubMed]

158. Eissa, M.M.; Ismail, C.A.; El-Azzouni, M.Z.; Ghazy, A.A.; Hadi, M.A. Immuno-therapeutic potential of Schistosoma mansoni and Trichinella spiralis antigens in a murine model of colon cancer. Investig. New Drugs 2019, 37, 47-56. [CrossRef]

159. Almeida, G.F.G.; Sarinho, F.W.; Carvalho de Abreu, E.; Lima, P.; Oliveira Filho, J.B.; Moura, M.A.d.L.; Ribeiro, L.N.B.; Rolim de Brito, B.; Lira, M.M.d.M.; Maior, M.d.R.M.S.; et al. DNA repair defect and RAS mutation in two patients with Schistosoma mansoni-associated colorectal cancer: Carcinogenesis steps or mere coincidence? J. Glob. Oncol. 2017, 3, 423-426. [CrossRef]

160. Nacif-Pimenta, R.; da Silva Orfanó, A.; Mosley, I.A.; Karinshak, S.E.; Ishida, K.; Mann, V.H.; Coelho, P.M.Z.; da Costa, J.M.C.; Hsieh, M.H.; Brindley, P.J.; et al. Differential responses of epithelial cells from urinary and biliary tract to eggs of Schistosoma haematobium and S. mansoni. Sci. Rep. 2019, 9, 10731. [CrossRef]

161. Schatoff, E.M.; Leach, B.I.; Dow, L.E. Wnt signaling and colorectal cancer. Curr. Colorectal Cancer Rep. 2017, 13, 101-110. [CrossRef] [PubMed] 